\title{
Sistem Pendukung Keputusan Penentuan Lahan Pertanian, Pertambangan, dan Perindustrian (SOFTPLET) dengan Menggunakan Metode SMARTER
}

\author{
Amak Yunus, Achmad Cholirul Rohman
}

\begin{abstract}
Abstrak-Kota Malang masih mempunyai lahan yang kosong dan tidak terawat padahal lahan tersebut ketika di manfaatkan dan dikelolah dengan baik bisa membantu perekonomian penduduk di daerah sekitar yang masih belum stabil semakin banyaknya lahan pertanian, pertambangan, dan perindustrian maka ekonomi dan lapangan kerja juga akan semakin banyak sehingga bisa mengurangi angka pengangguran dan tindak kriminal yang ada di kota malang karena masalah perekonomian oleh itu pula penulis membuat sebuah Sistem Pendukung Keputusan penentuan lahan pertanian, pertambangan, dan perindustrian (softplet) dengan metode smarter di kota malang yang dapat membantu pemanfaatan lahan kosong dan tidak terawat. Dalam pengembangan sistem informasi penentuan letak lahan pertanian, pertambangan, dan perindustrian ini penulis menggunakan bahasa pemrograman WEB dan MySQL 5.0 sebagai database servernya. Untuk perancangannya menggunakan metode terstruktur yang menggunakan UML sebagai alat bantu untuk merancang aplikasi pengembangan Sistem Pendukung Keputusan penentuan lahan pertanian, pertambangan, dan perindustrian dengan metode smarter (softplet) di kota malang. Pengembangan Sistem Pendukung Keputusan penentuan lahan pertanian, pertambangan, dan perindustrian diharap bisa membantu pengolahan dan pemanfaatan lahan kosong yang tidak terpakai sebagai lahan pekerjaan serta meminimalisir tingkat pengangguran dan tindak kriminal karena masalah perekonomian.
\end{abstract}

Kata Kunci-Pertanian, Pertambangan, Perindustrian, Sistem Pendukung Keputusan , dan pemanfaatan Lahan Kosong.

\section{PEndahuluan}

$\mathrm{P}$ ertumbuhan ekonomi Indonesia yang terus meningkat secara fluktuatif berdampak pada meningkatnya perkembangan wilayah.

Perkembangan suatu wilayah ditandai oleh perkembangan sektor ekonomi dan peningkatan kelengkapan fasilitas-fasilitas umum seperti sekolah, pertokoan, industri, dan lain sebagainya. Sejalan dengan itu, pembangunan fasilitas umum yang masif di wilayah yang berkembang menjadi daya tarik penduduk wilayah lain dan proses ini mendorong pertambahan penduduk secara signifikan. Salah satu permasalahan akibat meningkatnya perkembangan suatu wilayah adalah persaingan yang semakin tajam dalam pemanfaatan lahan khususnya antara lahan pertanian dan lahan nonpertanian. Persaingan ini didorong oleh peningkatan kebutuhan sumberdaya lahan untuk berbagai jenis kebutuhan seperti kebutuhan pangan, permukiman dan area beraktifitas berupa pelayanan umum. Kebutuhan pangan membutuhkan lahan pertanian untuk berproduksi, sedangkan permukiman dan sarana pelayanan umum membutuhkan kawasan permukiman dan lahan terbangun. Dalam kondisi demikian, penggunaan lahan pertanian akan berpeluang besar untuk dialihgunakan menjadi penggunaan nonpertanian. Berdasarkan teori nilai ekonomi lahan secara umum dinyatakan bahwa nilai ekonomi lahan pertanian umumnya lebih rendah dibandingkan dengan lahan nonpertanian. Perbedaan nilai tersebut menjadi salah satu sebab terjadinya perubahan penggunaan lahan pertanian menjadi non-pertanian (Nasoetion dan Winoto, 1996).

Indonesia secara regional berada pada dua buah lempeng besar yaitu lempeng Pacifik di Utara dan lempeng Australia di Selatan. Akibat tumbukan kedua lempeng tersebut, telah menempatkan Indonesia menjadi salah satu wilayah Negara yang rawan dengan bencana gempa bumi, tsunami dan letusan gunung berapi. Namun, dibalik bencana alam akibat tumbukan dua lempeng tersebut,membawa hikmah yang tak ternilai harganya. Akibat aktifitas pergerakan kedua lempeng tersebut pulalah akhirnya menghasilkan tatanan tektonik yang lengkap. Kondisi geologi demikian mendukung pembentukan minaeralisasi berbagai mineral atau bahan galian berharga sebagai anugerah Tuhan YME yang patutdisyukuri, misalnya mineral logam dan lain-lain (Sujono:2004).

Industri merupakan salah satu upaya untuk meningkatkan kesejateraan penduduk. Selain itu industrialisasi juga tidak terlepas dari usaha untuk meningkatkan mutu sumberdaya manusia dan kemampuan untuk memanfaatkan sumber daya alam secara optimal. Undang-Undang Nomor 5 Tahun 1984 tentang Perindustrian, industri adalah kegiatan ekonomi yang mengelola bahan mentah, bahan baku, barang setengah jadi, dan atau barang jadi menjadi barang dengan nilai yang lebih tinggi untuk penggunaanya termasuk kegiatan rancangan bangun dan perekayasaan industri. Dari sudut pandang geografi, Industri sebagai suatu sistem, merupakan perpaduan sub sistem fisis dan sub sistem manusia (Sritomo Wignjosoebroto, 2003).

Melihat itu semua maka proyek akhir ini bertema "Sistem Pendukung Keputusan penentuan lahan perindustrian, pertanian, dan pertambangan (SOFTPLET) dengan metode Smarter di Kota Malang". 
Yang bisa membantu para pemilik lahan untuk menentukan letak lahan pertanian, pertambangan dan perindustrian sehingga bisa membantu pemanfaatan lahan kosong dan perekonomian penduduk sekitar dengan harapan masalah perekonomian bisa teratasi.

\section{TINJAUAN PUSTAKA}

Pertanian adalah suatu bentuk produksi yang khas, yang didasarkan pada proses pertumbuhan tanaman dan hewan. Petani mengelola dan merangsang pertumbuhan tanaman dan hewan dalam suatu usaha tani, dimana kegiatan produksi merupakan bisnis, sehinggga pengeluaran dan pendapatan sangat penting artinya(Mosher :1966).

Usaha Pertambangan adalah sebagian atau seluruh tahapan kegiatan dalam rangka penelitian, pengelolaan dan pengusahaan mineral dan batubara yang meliputi penyelidikan umum, eksplorasi, studi kelayakan, konstruksi, penambangan pengolahan dan pemurnian, pengangkutan dan penjualan serta kegiatan pasca tambang (Pasal 1 butir 6 Undang-Undang No.4 tahun 2009 tentang Pertambangan Mineral dan Batubara).

Industri adalah suatu unit atau atau kesatuan produk yang terletak pada suatu tempat tertentu yang meletakkan kegiatan untuk menubah barang-barang secara mekanis atau kimia, sehingga menjadi barang (produk baru yang sifatnya lebih dekat pada konsumen terakhir), termasuk disini memasang bahagian dari suatu barang (ansembling) (Toto Hadikusumo 1990).

Desain sistem adalah proses pengembangan spesifikasi sistem baru berdasarkan rekomendasi hasil analisis sistem. Dalam tahap desain, tim kerja desain harus merancang dalam berbagai kertas kerja mengenai spesifikasi yang dimaksud. Kertas kerja dimaksud memuat berbagai uraian mengenai input, proses dan output dari sistem yang diusulkan.

UML (Unified Modeling Language) adalah metode pemodelan secara visual sebagai sarana untuk merancang dan atau membuat Sistem Pendukung Keputusan berorientasi objek. Karena UML inimerupakan bahasa visual untuk pemodelan bahasa berorientasi objek, maka semua elemen dan diagram berbasiskan pada paradigma object oriented. UML adalah salah satu tool / model untuk merancang pengembangan Sistem Pendukung Keputusan yang berbasis object oriented. $U M L$ sendiri juga memberikan standar penulisan sebuah sistem blue print, yang meliputi konsep bisnis proses, penulisan kelas-kelas dalam bahasa program yang spesifik, skema database, dan komponen- komponen yang diperlukan dalam sistem Sistem Pendukung Keputusan . UML sebagai sebuah bahasa yang memberikan vocabulary dan tatanan penulisan kata-kata dalam 'MS Word' untuk kegunaan komunikasi. Sebuah bahasa model adalah sebuah bahasa yang mempunyai vocabulary dan konsep tatanan / aturan penulisan serta secara fisik mempresentasikan dari sebuah sistem. $U M L$ adalah sebuah bahasa standar untuk pengembangan sebuah Sistem Pendukung Keputusan yang dapat menyampaikan bagaimana membuat dan membentuk model-model, tetapi tidak menyampaikan apa dan kapan model yang seharusnya dibuat yang merupakan salah satu proses implementasi pengembangan Sistem Pendukung Keputusan . UML tidak hanya merupakan sebuah bahasa pemograman visual saja, namun juga dapat secara langsung dihubungkan ke berbagai bahasa pemograman, seperti JAVA, C++, Visual Basic, atau bahkan dihubungkan secara langsung ke dalam sebuah object-oriented database. Begitu juga mengenai pendokumentasian dapat dilakukan seperti; requirements, arsitektur, design, source code, project plan, tests, dan prototypes. Untuk dapat memahami $U M L$ membutuhkan bentuk konsep dari sebuah bahasa model, dan mempelajari 3 (tiga) elemen utama dari $U M L$, seperti building block, aturan-aturan yang menyatakan bagaimana building block diletakkan secara bersamaan, dan beberapa mekanisme umum (common).

\section{PEMBAHASAN}

Analisis kebutuhan non fungsional dilakukan untuk mengetahui spesifikasi kebutuhan untuk sistem. Spesifikasi kebutuhan melibatkan analisis perangkat keras/hardware,analisis perangkat lunak/Sistem Pendukung Keputusan ,analisis pengguna/user.

Tujuan dari penyusunan tugas akhir ini adalah untuk menghasilkan sebuah Sistem Pendukung Keputusan Penenentuan Letak Lahan Perinsdustrian, Pertanian, dan Pertambangan (SOFTPLET) di kota malang sebagai pemecahan dari permasalahan yang diangkat. Untuk menghasilkan SOFTPLET ada beberapa tahapan yang harus dilakukan:

Kebutuhan perangkat keras(Hardware) yang diperlukan untuk mengimplementasikan softplet memiliki spesifikasi sebagai berikut:

TABEL I KeBUTUHAN PERANGKAT KERAS

\begin{tabular}{|c|c|c|c|}
\hline No. & $\begin{array}{c}\text { Nama } \\
\text { Barang }\end{array}$ & Jumlah & Keterangan \\
\hline 1 & Komputer & 1 & $\begin{array}{l}\text { a) Processor intel } \\
\text { Pentium Dual Core } \\
\text { @ } 2 \mathrm{GHz} \\
\text { b) Hardisk 80 GB } \\
\text { c) Memori 1024 MB } \\
\text { d) VGA 128 MB } \\
\text { e) Monitor LCD 15" }\end{array}$ \\
\hline 2 & $\begin{array}{l}\text { Mouse dan } \\
\text { Keyboard } \\
\end{array}$ & 1 & $\begin{array}{l}\text { Input dan pengolahan } \\
\text { data }\end{array}$ \\
\hline 3 & Modem & 1 & Koneksi data ke internet \\
\hline 4 & Printer & 1 & Print out data \\
\hline
\end{tabular}

Spesifikasi perangkat lunak yang dibutuhkan untuk mendukung aplikasi yang akan dibangun (Sistem Pendukung Keputusan penentuan lahan Pertanian, Pertambangan, dan perindustrian dengan menggunakan metode smarter di Kota Malang) adalah sebagai berikut: TABEL II KebUtUhAN PERANGKAT LUNAK

\begin{tabular}{cll}
\hline No. & \multicolumn{1}{c}{ Perangkat Lunak } & \multicolumn{1}{c}{ Keterangan } \\
\hline 1 & Windows 7, 8, dan 10 & Sistem Operasi \\
\hline 2 & $\begin{array}{l}\text { Mozilla firefox, Internet } \\
\text { Explorer dan Opera }\end{array}$ & Browser \\
\hline 3 & Microsoft Office 2010 & Pembuatan Laporan \\
\hline 4 & Photoshop & Desain background aplikasi \\
\hline
\end{tabular}




\begin{tabular}{|c|c|c|c|c|}
\hline$\overline{\mathrm{Co}}$ & \multirow{2}{*}{\multicolumn{2}{|c|}{$\begin{array}{l}\text { Coreldraw } \\
\text { PHP, CSS, Java Script }\end{array}$}} & \multicolumn{2}{|c|}{ Desain background aplikasi } \\
\hline $\mathrm{PH}$ & & & \multicolumn{2}{|c|}{$\begin{array}{l}\text { Aplikasi Penentuan lahar } \\
\text { perindustrian, pertanian, dar } \\
\text { pertambangan }\end{array}$} \\
\hline $\mathrm{M}$ & \multirow{2}{*}{\multicolumn{2}{|c|}{ Google Map }} & \multicolumn{2}{|c|}{ Database } \\
\hline $\mathrm{Gc}$ & & & \multicolumn{2}{|c|}{$\begin{array}{l}\text { Penentuan } \\
\text { geografis } \\
\text { satelit }\end{array}$} \\
\hline So & \multicolumn{2}{|c|}{ Soilinfo } & \multicolumn{2}{|c|}{ Untuk mengetahui info tanah } \\
\hline \multicolumn{5}{|c|}{$\begin{array}{l}\text { Karakteristik user yang ada saat ini yaitu berumur } 17 \\
\text { sampai } 40 \text { tahun. User terdiri dari Manager dan staff } \\
\text { Public Relationship yang memiliki jenjang pendidikan } \\
\text { sarjana. Sebagian besar user memiliki pengalaman yang } \\
\text { hampir sama secara keseluruhan dalam mengoperasikan } \\
\text { komputer dan memahami program-program aplikasi } \\
\text { tetapi sudah cukup berpengalaman dalam } \\
\text { mengoperasikan sistem Operasi Windows, bekerja } \\
\text { menggunakan Microsoft Office seperti Microsoft Office } \\
\text { Word dan Microsoft Office Excel, dan dapat } \\
\text { menggunakan Internet dengan baik. } \\
\text { Perangkat lunak yang akan dibangun akan digunakan } \\
\text { oleh tiga jenis user.Untuk lebih jelasnya dapat dilihat } \\
\text { pada table dibawah ini. } \\
\text { TABEL III KEBUTUHAN UsER }\end{array}$} \\
\hline User & $\begin{array}{c}\text { Tingkat } \\
\text { Pendidikan }\end{array}$ & \multicolumn{2}{|c|}{$\begin{array}{c}\text { Tingkat } \\
\text { Ketrampilan }\end{array}$} & Pengalaman \\
\hline \multicolumn{2}{|l|}{ User } & \multicolumn{2}{|c|}{$\begin{array}{l}\text { Bisa } \\
\text { mengikuti } \\
\text { petunjuk } \\
\text { yang ada } \\
\text { pada sistem }\end{array}$} & $\begin{array}{l}\text { Minimal } \\
\text { mampu } \\
\text { mengoperasikan } \\
\text { computer dan } \\
\text { bias } \\
\text { menggunakan } \\
\text { aplikasi } \\
\text { browser }\end{array}$ \\
\hline Admin & $\begin{array}{l}\text { Sesuai } \\
\text { dengan } \\
\text { ketentuan } \\
\text { perusahaan }\end{array}$ & & $\begin{array}{l}\text { kuti } \\
\text { uk ada } \\
\text { istem }\end{array}$ & $\begin{array}{l}\text { Minimal } \\
\text { mampu } \\
\text { mengoperasikan } \\
\text { computer dan } \\
\text { bias } \\
\text { menggunakan } \\
\text { aplikasi } \\
\text { browser } \\
\end{array}$ \\
\hline $\begin{array}{l}\text { Sofplet } \\
\text { Technician }\end{array}$ & $\begin{array}{l}\text { Sesuai } \\
\text { dengan } \\
\text { ketentuan } \\
\text { perusahaan }\end{array}$ & & raman & $\begin{array}{l}\text { Menguasai } \\
\text { Bahasa } \\
\text { pemrograman } \\
\text { Web }\end{array}$ \\
\hline
\end{tabular}

Sistem yang akan dibangun dalam tugas akhir ini adalah sebuah Sistem Pendukung Keputusan Penenentuan Letak Lahan Perinsdustrian, Pertanian, dan Pertambangan (SOFTPLET), untuk mendapatkan informasi-informasi tentang penentuan sebuah lahan kosong yang masih bisa dimanfaatkan kembali untuk sebuah Perindustrian, Pertanian, dan Pertambangan. Pengguna SOFTPLET akan sangat membantu sekali dalam pemanfaatan lahan kosong yang sebelumnya tidak di ketahui. Untuk membantu menjelasan gambaran yamg dimaksud penelti menggunakan $U M L$ yang merupakan singkatan dari "Unified Modelling Language" yaitu suatu metode permodelan secara visual untuk sarana perancangan sistem berorientasi objek, atau definisi $U M L$ yaitu sebagai suatu bahasa yang sudah menjadi standar pada visualisasi, perancangan dan juga pendokumentasian sistem Sistem Pendukung

.

Sisten Pendukung Keputusan bisa mengetahui letak geografis sebuah lahan.

3. Sistem Pendukung Keputusan bisa menentukan jenis tanah.

4. Sistem Pendukung Keputusan bisa menentukan tanaman yang cocok pada suatu lahan.

5. Sistem Pendukung Keputusan bisa menentukan tambang yang cocok pada suatu lahan.

6. Sistem Pendukung Keputusan bisa menentukan industri yang cocok pada sustu lahan.

Use case diagram ini dibuat untuk menentukan hak akses yang akan di miliki oleh user dalam menggunakan Sistem Pendukung Keputusan Penentuan letak lahan pertanian, Perindustrian, dan Pertambangan (SOFTPLET).

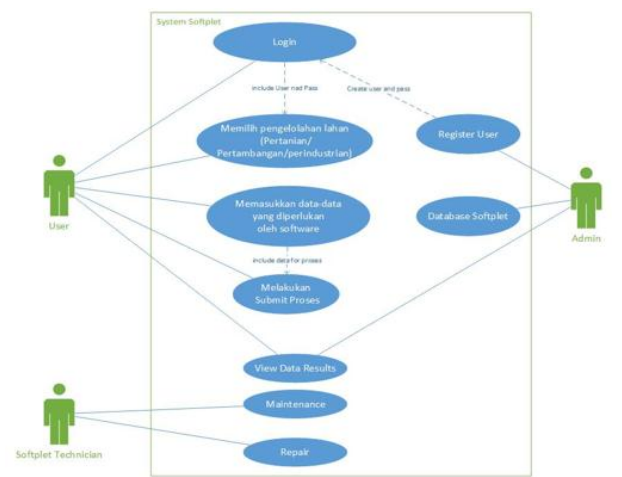

Gambar 1. Use Case Diagram

Activity diagram ini lebih memfokus kepada pemnggambaran proses dan urutan aktivitas dalam sebuah aplikasi. Dipakai pada Sistem Pendukung Keputusan Penentuan Letak Lahan Pertanian, Perindustrian dan Pertambangan (SOFTPLET) untuk memperlihatkan urutan aktifitas proses. Memiliki struktur diagram yang mirip flowchart atau data flowdiagram pada perancangan terstruktur. Memiliki pula manfaat yaitu apabila kita membuat diagram ini terlebih dahulu dalam memodelkan sebuah proses untuk membantu memahami proses secara keseluruhan. Dan Activity dibuat berdasarkan sebuah atau beberapa use case pada use case diagram.

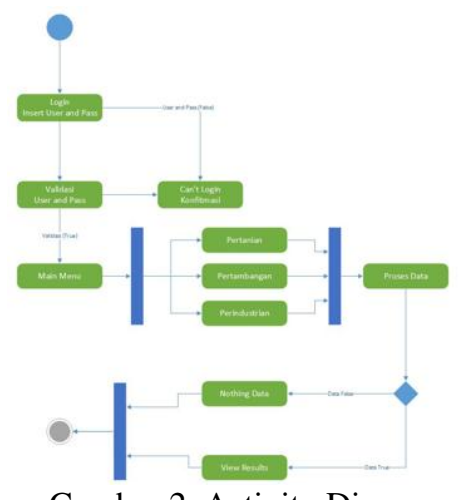

Gambar 2. Activity Diagram 
Sequence diagram ini menjelaskan interaksi objek yang berdasarkan urutan waktu dan menggambarkan urutan atau tahapan yang harus dilakukan untuk dapat menghasilkan sesuatu prorse kerja softplet seperti pada use case diagram.

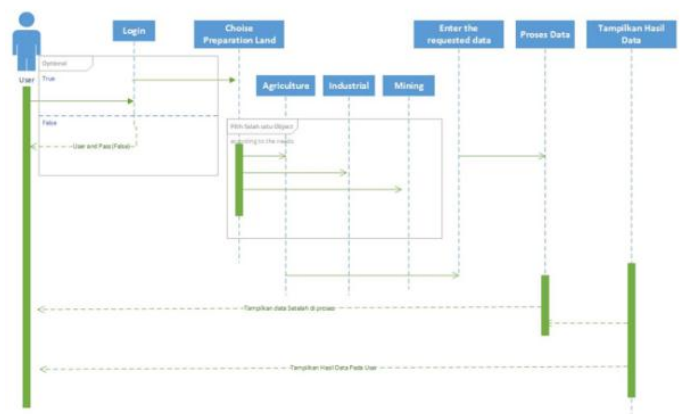

Gambar 3. Squence Diagram

Class diagram ini menggambarkan struktur dan penjelasan Class, paket, dan objek serta hubungan satu sama lain seperti containment, pewarisan, asosiasi, dan lain-lain. Class diagram juga menjelaskan hubungan antar Class dalam sebuah sistem yang sedang dibuat dan bagaimana caranya agar mereka saling berkolaborasi untuk mencapai sebuah tujuan.

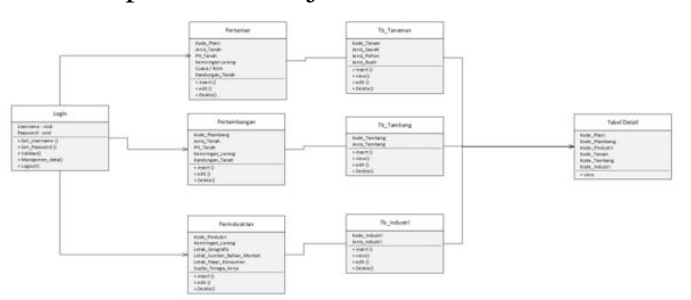

Gambar 4. Class Diagram

Metode yang digunakan oleh penulis disini adalah SMART ( Simple Multi Attribute Rating Technique ) merupakan metode pengambilan keputusan yang multiatribut yang dikembangkan oleh Edward pada tahun 1977. Teknik pembuatan keputusan multiatribut ini digunakan untuk mendukung pembuat keputusan dalam memilih antara beberapa alternatif. Setiap pembuat keputusan harus memilih sebuah alternatif yang sesuai dengan tujuan yang telah dirumuskan.Setiap alternatif terdiri dari sekumpulan atribut dan setiap atribut mempunyai nilai-nilai. Nilai ini dirata-rata dengan skala tertentu. Setiap atribut mempunyai bobot yang menggambarkan seberapa penting dibandingkan dengan atribut lain. Pembobotan dan pemberian peringkat ini digunakan untuk menilai setiap alternatif agar diperoleh alternatif terbaik. Pembobotan pada SMART ( Simple Multi Attribute Rating Technique) menggunakan skala antara 0 sampai 1, sehingga mempermudah perhitungan dan perbandingan nilai pada masing-masing alternatif. Model yang digunakan dalam SMART (Simple Multi Attribute Rating Technique) yaitu

$$
u\left(a_{i}\right)=\sum_{j=1}^{m} w_{j} u_{i}\left(a_{i}\right), i=1,2 \ldots m
$$

Keterangan:

wj = nilai pembobotan kriteria ke-j dan $\mathrm{k}$ kriteria

$\mathrm{u}(\mathrm{ai})=$ nilai utility kriteria ke-i untuk kriteria ke-i
Pemilihan keputusan adalah mengidentifikasi mana dari $\mathrm{n}$ alternatif yang mempunyai nilai fungsi terbesar.

Teknik Metode SMART:

1. menentukan jumlah kriteria

2. sistem secara default memberikan skala

0-100 berdasarkan prioritas yang telah diinputkan kemudian dilakukan normalisasi.

Normalisasi $=\frac{w_{j}}{\sum w_{j}}$

Keterangan : wj : bobot suatu kriteria

3. memberikan nilai kriteria untuk

setiap alternatif.

4. hitung nilai utility untuk setiap

kriteria masing-masing.

$$
u_{i}\left(a_{i}\right)=100 \frac{\left(C_{\max }-C_{\text {out }}\right)}{\left(C_{\max }-C_{\min }\right)} \%
$$

Keterangan :

ui(ai) : nilai utility kriteria ke-1 untuk kriteria ke-i

Cmax : nilai kriteria maksimal

Cmin : nilai kriteria minimal

Cout i : nilai kriteria ke-i

Desain perancangan aplikasi ini adalah perancangan desain aplikasi Sotfware Penentuan letak Lahan Pertanian, Perindustrian, dan Pertambangan (SOFTPLET) yang akan dibuat oleh penulis. Desain ini membantu penulis dalam mengaplikasikan tata letak tools yang akan digunakan pada program sehingga user tidak merasa kesulitan dalam menjalankan atau menggunakan program. Gambar perancangan aplikasi SOFTPLET terlihat pada gambar 5 sampai dengan gambar 10.

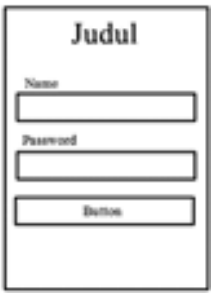

Gambar 5 Rancangan Form Login

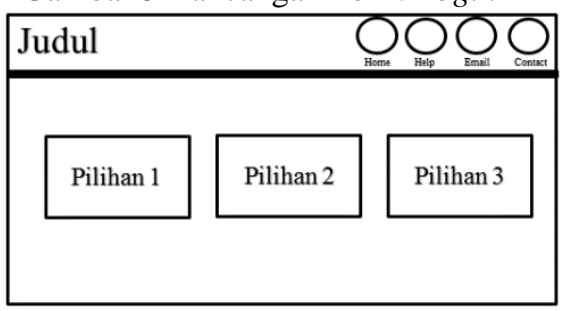

Gambar 6 Rancangan Menu Utama 


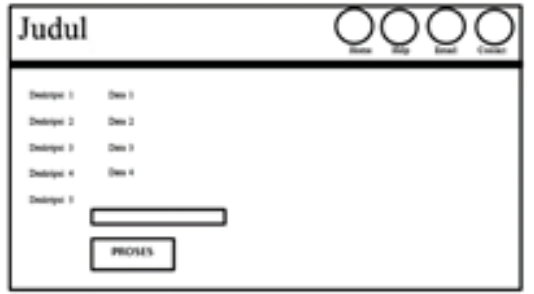

Gambar 7 Rancangan Form Pertanian

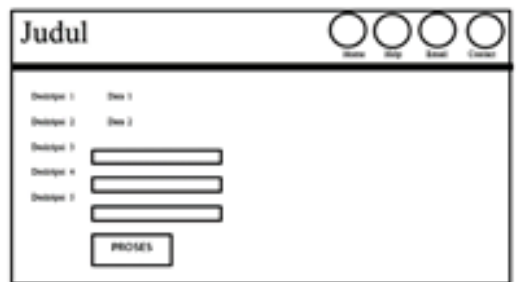

Gambar 8 Rancangan Form Pertambangan

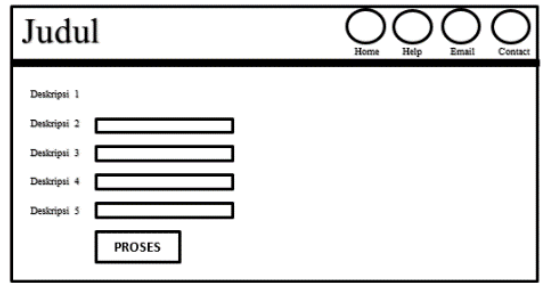

Gambar 9 Rancangan From Perindustrian

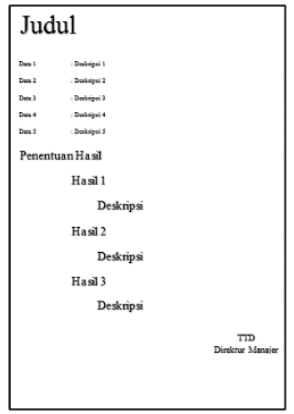

Gambar 10 Rancangan Hasil Laporan

Perhitungan pada Smarter berdasarkan kriteria yang akan kita ambil untuk menentukan aktivitas pertambangan, pertanian, dan perindustrian. Klasifikasi Jenis tanah ini di prioritaskan berdasarkan kadar $P h$ yang terkandung pada tanah tampak pada tabel 6.

\begin{tabular}{|c|c|c|c|c|c|}
\hline Kriteria & $\begin{array}{c}\text { Nama } \\
\text { Indikator }\end{array}$ & $\begin{array}{c}\text { Kemiringan } \\
\text { (derajat) }\end{array}$ & $\begin{array}{l}\text { Priori } \\
\text { tas }\end{array}$ & Rumus & Bobot \\
\hline \multirow{5}{*}{$\begin{array}{l}\text { Kemiringan } \\
\text { Lereng }\end{array}$} & Datar & $0 \mathrm{~s} / \mathrm{d} 8$ & 1 & $(1+1 / 2+1 / 3+1 / 4+1 / 5) / 5$ & 0,46 \\
\hline & Landai & $>8 \mathrm{~s} / \mathrm{d} 15$ & 2 & $(0+1 / 2+1 / 3+1 / 4+1 / 5) / 5$ & 0,26 \\
\hline & $\begin{array}{c}\text { Agak } \\
\text { Curam }\end{array}$ & $>15 \mathrm{~s} / \mathrm{d} 25$ & 3 & $(0+0+1 / 3+1 / 4+1 / 5) / 5$ & 0,16 \\
\hline & Curam & $>25 \mathrm{~s} / \mathrm{d} 45$ & 4 & $(0+0+0+1 / 4+1 / 5) / 5$ & 0,09 \\
\hline & $\begin{array}{l}\text { Sangat } \\
\text { Curam }\end{array}$ & $>45$ & 5 & $(0+0+0+0+1 / 5) / 5$ & 0,04 \\
\hline
\end{tabular}

Iklim atau cuaca sangat menentukan untuk melakukan sebuah aktivitas pertanian, pertambangan, dan perindustrian (tabel 7). Sehingga ketika melakukan sebuah aktivitas kita harus melihat iklim terlebih dahulu.

Tabel 7 Pembobotan Pada Iklim

\begin{tabular}{ccccc}
\hline Kriteria & $\begin{array}{c}\text { Nama } \\
\text { Indikator }\end{array}$ & $\begin{array}{c}\text { Kemiringan } \\
\text { (derajat) }\end{array}$ & Rumus & Bobot \\
\hline \multirow{2}{*}{ Iklim/Cuaca } & $\begin{array}{c}\text { Musim } \\
\text { Kemarau }\end{array}$ & $0 \mathrm{~s} / \mathrm{d} 8$ & $(1+1 / 2) / 2$ & 0,75 \\
\cline { 2 - 5 } & $\begin{array}{c}\text { Musim } \\
\text { Penghujan }\end{array}$ & $>8 \mathrm{~s} / \mathrm{d} 15$ & $(0+1 / 2) / 2$ & 0,25 \\
\hline
\end{tabular}

Pengambilan data disesuaikan pada lingkungan yang kita teliti.

Tabel 8 Pengambilan sampel data

\begin{tabular}{ccccc}
\hline No & Tempat & Jenis Tanah & $\begin{array}{c}\text { Kemiringan } \\
\text { Lereng }\end{array}$ & Iklim \\
\hline 1 & A & Alfisols & Datar & Musim Kemarau \\
\hline 2 & B & $\begin{array}{c}\text { Andisols / } \\
\text { Millosols }\end{array}$ & Landai & $\begin{array}{c}\text { Musim } \\
\text { Penghujan }\end{array}$ \\
\hline 3 & C & Entisols & Agak Curam & Musim Kemarau \\
\hline
\end{tabular}

Data yang sudah diambil berdasar kondisi lingkungan setelah diteliti akan dirubah kedalam betuk perhitungan smarter sehingga dapat ditentukan berapa jumlah persentase kemungkinan untuk melakukan pertanian, pertambangan, dan perindustrian. Data yang mempunyai bobot paling tinggilah yang akan kita ambil.

Tabel 9 Mengubah Data kedalam Perhitugan

\begin{tabular}{cccccc}
\hline No & Tempat & Jenis Tanah & Kemiringan Lereng & Iklim & Bobot \\
\hline 1 & $\mathrm{~A}$ & 0,370408163 & 0,456666667 & 0,75 & 1,577075 \\
\hline 2 & $\mathrm{~B}$ & 0,22755102 & 0,256666667 & 0,25 & 0,734218 \\
\hline 3 & $\mathrm{C}$ & 0,156122449 & 0,156666667 & 0,25 & 1,062789 \\
\hline
\end{tabular}

Dibawah ini adalah spesifikasi perangkat keras yang digunakan selama pembuatan sistem :
1. Type
: Lenovo
2. Sistem Operasi : Windows 7
3. Processor : Intel Inside
4. Memory :2 GB RAM
5. Storage Space : $500 \mathrm{~GB}$

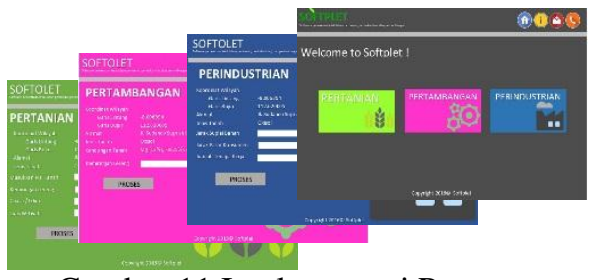

Gambar 11 Implementasi Program

\section{KESIMPULAN}

Berdasarkan pembahasan pada Sistem Pendukung Keputusan Penentuan Lahan Pertanian , Pertambangan dan Perindustrian (SOFTPLET) di Kota Malang telah disimpulkan bahwa :

1. SOFTPLET membantu penentuan Lahan Pertanian, Pertambangan dan Perindustrian dengan metode SMARTER yang sebelumnya kita inputkan kriteria untuk menentukan pengolahan lahan yang cocok.

2. Memotivasi pemilik lahan untuk menjadikan lahannya sebagai Pertanian, Pertambangan atau Perindustrian.

Beberapa saran untuk mengembangkan Sistem Pendukung Keputusan Penentuan Letak Lahan Pertanian, Pertambangan dan Perindustrian (SOFTPLET) di Kota Malang lebih lanjut adalah sebagai berikut:

1. Penelitian lanjutan perlu dilakukan untuk memperluas variabel yang diteliti untuk pengembangan Software Penentuan Letak Lahan Pertanian , Pertambangan dan Perindustrian (SOFTPLET) di Kota Malang.

2. Menambahkan pilihan fitur yang lebih variatif, sehingga pengguna mempunyai lebih banyak pilihan. 


\section{DAFTAR PUSTAKA}

[1] Alfita, Riza. 2008. Decision Support System Of Reserve Building Cultural Revitalization Determination Using Simple Multiattribute Rating Technique Exploiting Ranks Method. Madura: Universitas Trunojoyo.

[2] Arya Wardhana, Wisnu. 2004. Dampak Pencemaran Lingkungan. Jakarta: Andi Offset.

[3] Baker, D dkk. Guidebook to Decision Making Methods. USA: WSRC-IM-2002-00002, Department of Energy.

[4] Edwards, W. dkk. 1994. SMARTS and SMARTER. USA: Improved.

[5] Jacky, Miner. Teori Pertambangan I. (online) www.http./teoripertambangan-i.html diakses tgl 25/07/2013 pukul 10.00.

[6] Roberts, R. and Goodwin. P. 2002. Weight Approximations in Multi-attribute Decision Models. USA: Journal of Multi-Criteria Decision Analysis 11, pp. 291-303, Wiley.

[7] Salim HS. 2010. Hukum Pertambangan di Indonesia. Jakarta: Radja Grafindo.

[8] Siregar, Hendrik dkk. 2009. Potret Penutupan Tambang di Indonesia. Jakarta: Jatam.

[9] Sudrajat, Nandang. 2010. Teori dan Praktik Pertambangan di Indonesia Menurut Hukum. Yogyakarta: Pustaka Yustisia.

[10] Sujitno, Sutedjo. 2007. Sejarah Pertambangan Timah Di Indonesia, Abad 18 - Abad 20. Jakarta: Ibalat Communication.

[11] Sulton, Ali. 2011. Dampak Aktivitas Pertambangan Bahan Galian Golongan C terhadap Kondisi Kehidupan Masyarakat Desa. Bogor: Skripsi Institut Pertanian Bogor.

[12] Sutedi, Adrian. 2011. Hukum Pertambangan. Jakarta: Sinar Grafika. 